\title{
Development of microsatellite markers in Robinsonia (Asteraceae) an endemic genus of the Juan Fernández Archipelago, Chile
}

\author{
Koji Takayama $\cdot$ Patricio López Sepúlveda • \\ Gudrun Kohl · Johannes Novak · Tod F. Stuessy
}

Received: 1 August 2012/Accepted: 6 August 2012/Published online: 19 August 2012

(C) The Author(s) 2012. This article is published with open access at Springerlink.com

\begin{abstract}
Ten microsatellite markers were developed for Robinsonia (Asteraceae), a genus endemic to the Juan Fernández Archipelago, Chile. Polymorphisms of these markers were tested using one population each of $R$. evenia, $R$. gayana, and $R$. gracilis. The number of alleles for these markers ranged from 2 to 17 per locus, and expected heterozygosity ranged from 0 to 0.847 by population. A significant deviation from Hardy-Weinberg equilibrium was observed in zero to two markers in each population, and no significant linkage disequilibrium between markers was detected. The markers reported here would be useful for evolutionary studies and conservation strategies in Robinsonia.
\end{abstract}

Keywords Genetic diversity - Oceanic islands .

Pyrosequencing $\cdot$ Robinsonia

Oceanic islands are significant ecosystems for the conservation of global plant diversity due to their small areas and high levels of endemism in comparison with continental regions (Kier et al. 2009). Tiny population sizes and unique characteristics of insular endemic species make them particularly sensitive to anthropogenic disturbances (Frankham 1997).

K. Takayama ( $₫)$ · P. López Sepúlveda · G. Kohl ·

T. F. Stuessy

Department of Systematic and Evolutionary Botany,

Biodiversity Center, University of Vienna, Rennweg 14,

1030 Vienna, Austria

e-mail: gen33takayama@gmail.com

J. Novak

Institute for Applied Botany and Pharmacognosy,

University of Veterinary Medicine, Veterinärplatz 1,

1210 Vienna, Austria
The Juan Fernández Archipelago is located in the Pacific Ocean $667 \mathrm{~km}$ west of continental Chile, and it consists of two major islands of different geological ages, Robinson Crusoe Island (4 million years old) and Alejandro Selkirk Island (1-2 million years old) (Stuessy et al. 1984). The flora of the Archipelago contains 132 endemic vascular plants (Marticorena et al. 1998), $74 \%$ of which is regarded as "threatened" based on IUCN criteria (Ricci 2006). Biodiversity assessement in this archipelago, including population genetic study, is a pressing need as is the case with other oceanic islands (Caujape-Castells et al. 2010).

The genus Robinsonia DC. (Asteraceae) is endemic to the archipelago, and consists of eight species (Sanders et al. 1987; Danton and Perrier 2006). It should be pointed out that Pelser et al. $(2007,2010)$ suggested submergence of all species of Robinsonia into the large genus Senecio in order to maintain strict holophyly of the latter, which would obviate endemic generic status for Robinsonia. We do not follow this suggestion, however, as we prefer to recognize Robinsonia as generically distinct based on its striking divergence in morphological features, such as a dioecious breeding system and a rosette tree habit. Morphological and ecological divergences occur among Robinsonia species, and genetic divergence among them has also been demonstrated with isozyme and ITS markers (Crawford et al. 1992; Sang et al. 1995). In view of the estimated ages of the islands, species of Robinsonia have diversified cladogenetically within the past 4 million years (Stuessy et al. 1990). Most of the species in Robinsonia are considered to be highly threatened (Ricci 2006). In this present study, we develop microsatellite markers for investigating evolutionary processes within the genus.

We used one individual of $R$. masafuerae Skottsb. for isolation of microsatellites, plus one individual each of $R$. evenia Phil., $R$. gayana Decne., $R$. gracilis Decne., 


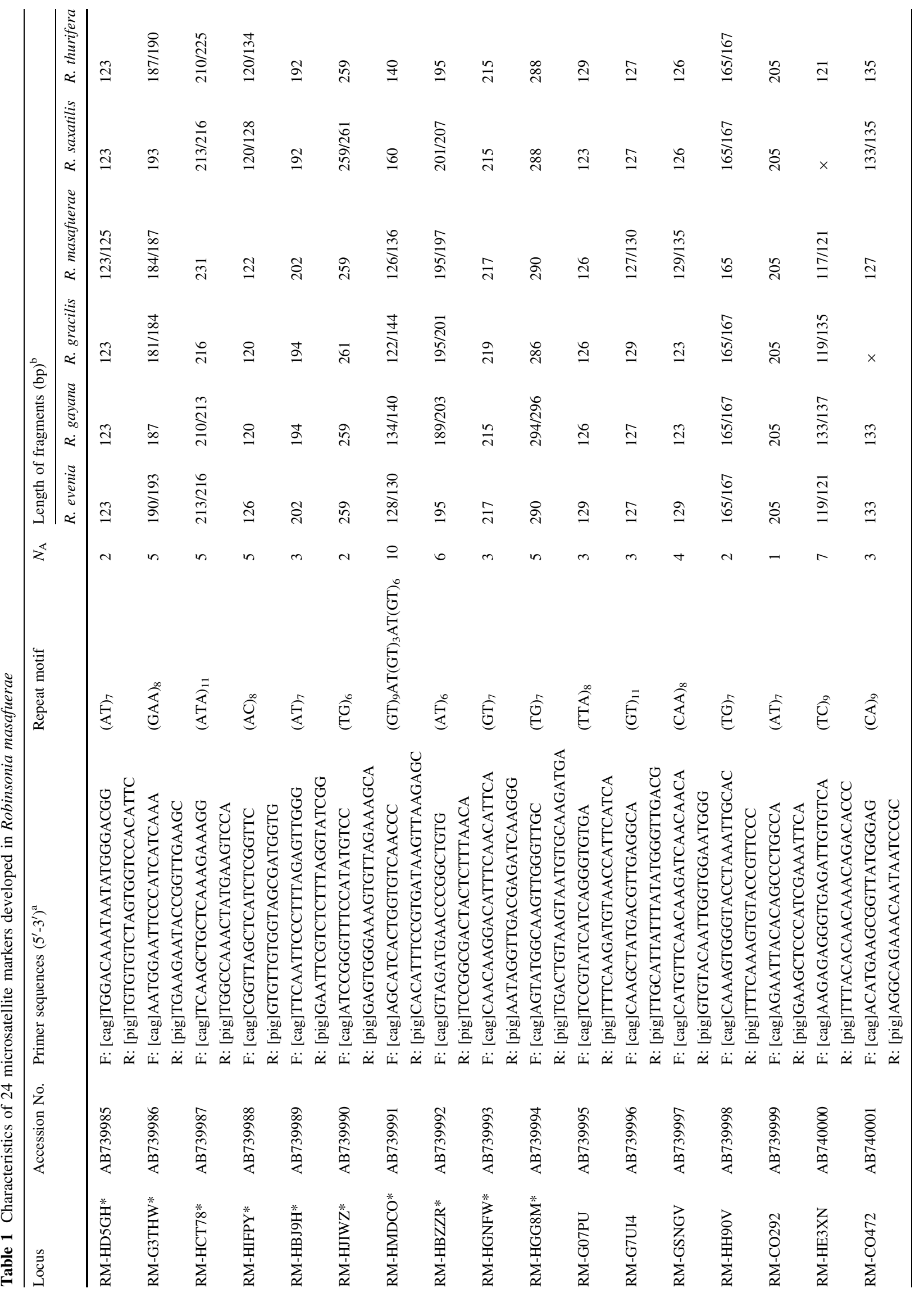




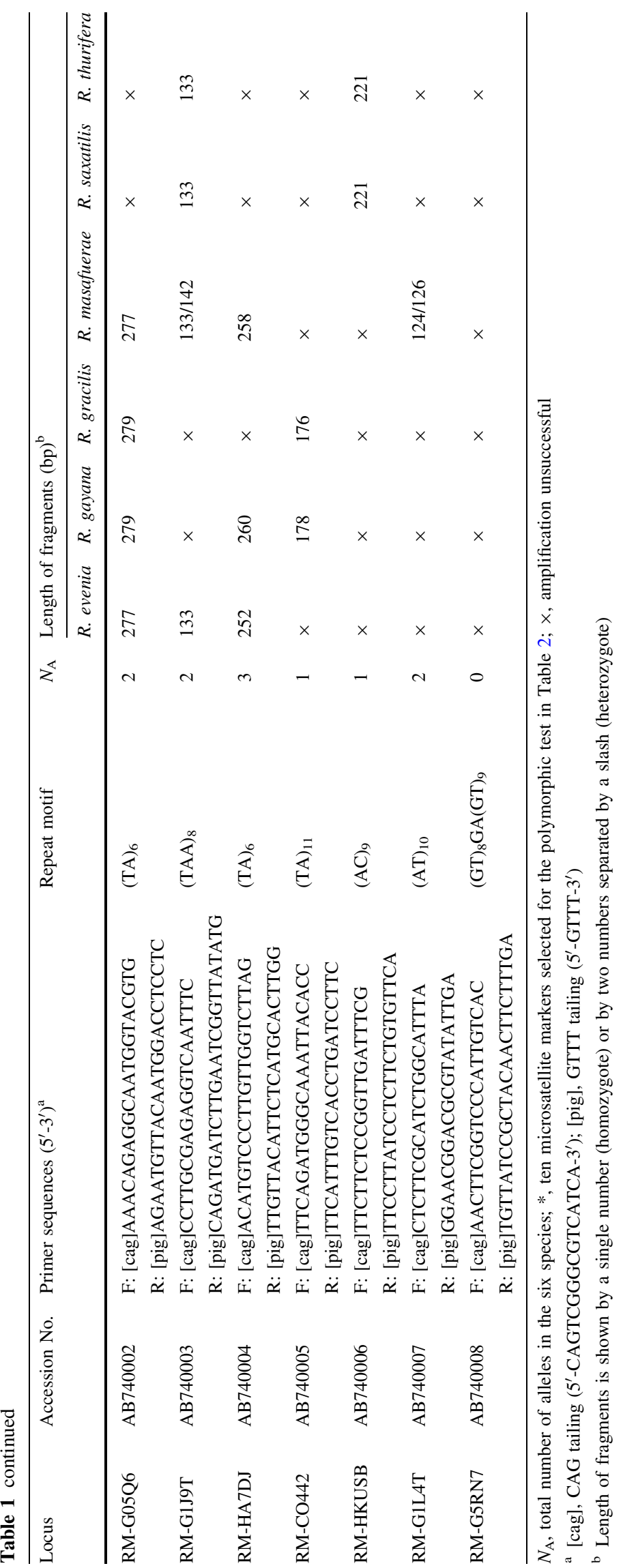


Table 2 Results of ten microsatellite markers in $R$. evenia, $R$. gayana, and $R$. gracilis

\begin{tabular}{|c|c|c|c|c|c|c|c|c|c|c|c|c|c|}
\hline \multirow[t]{2}{*}{ Marker } & \multirow{2}{*}{$\begin{array}{l}\text { All } \\
T_{\mathrm{A}}\end{array}$} & \multicolumn{4}{|c|}{ R. evenia $(\mathrm{n}=37)$} & \multicolumn{4}{|c|}{$R$. gayana, population $2(\mathrm{n}=18)$} & \multicolumn{4}{|c|}{$R$. gracilis, population $2(\mathrm{n}=29)$} \\
\hline & & $N_{\mathrm{A}}$ & $H_{\mathrm{O}}$ & $H_{\mathrm{E}}$ & $F_{\text {IS }}$ & $N_{\mathrm{A}}$ & $H_{\mathrm{O}}$ & $H_{\mathrm{E}}$ & $F_{\text {IS }}$ & $N_{\mathrm{A}}$ & $H_{\mathrm{O}}$ & $H_{\mathrm{E}}$ & $F_{\text {IS }}$ \\
\hline RM-HD5GH & 4 & 1 & 0.000 & 0.000 & NA & 1 & 0.000 & 0.000 & NA & 4 & 0.241 & 0.640 & $0.623 *$ \\
\hline RM-G3THW & 5 & 2 & 0.351 & 0.407 & 0.136 & 3 & 0.056 & 0.156 & $0.644 *$ & 2 & 0.483 & 0.485 & 0.005 \\
\hline RM-HCT78 & 10 & 6 & 0.595 & 0.589 & -0.009 & 8 & 0.833 & 0.844 & 0.013 & 3 & 0.552 & 0.527 & -0.046 \\
\hline RM-HIFPY & 8 & 4 & 0.541 & 0.551 & 0.019 & 4 & 0.500 & 0.608 & 0.178 & 3 & 0.138 & 0.347 & $0.603 *$ \\
\hline RM-HBJ9H & 5 & 3 & 0.270 & 0.349 & 0.226 & 2 & 0.278 & 0.313 & 0.113 & 3 & 0.379 & 0.511 & 0.258 \\
\hline RM-HJIWZ & 2 & 1 & 0.000 & 0.000 & NA & 1 & 0.000 & 0.000 & NA & 1 & 0.000 & 0.000 & NA \\
\hline RM-HMDCO & 17 & 5 & 0.432 & 0.581 & 0.255 & 10 & 0.944 & 0.847 & -0.115 & 3 & 0.448 & 0.424 & -0.058 \\
\hline RM-HBZZR & 5 & 1 & 0.000 & 0.000 & NA & 5 & 0.222 & 0.684 & $0.675^{*}$ & 2 & 0.552 & 0.471 & -0.172 \\
\hline RM-HGNFW & 3 & 2 & 0.054 & 0.053 & -0.028 & 1 & 0.000 & 0.000 & NA & 3 & 0.103 & 0.099 & -0.042 \\
\hline RM-HGC8M & 5 & 1 & 0.000 & 0.000 & NA & 3 & 0.778 & 0.549 & -0.416 & 1 & 0.000 & 0.000 & NA \\
\hline
\end{tabular}

$T_{\mathrm{A}}$, total number of alleles in the three populations; $N_{\mathrm{A}}$, total number of alleles within each population; $H_{\mathrm{O}}$, observed heterozygosity; $H_{\mathrm{E}}$, expected heterozygosity; $F_{\mathrm{IS}}$, inbreeding coefficient; $N A$, not applicable

*departs significantly from $\operatorname{HWE}(P<0.05)$

$R$. saxatilis Danton, and $R$. thurifera Decne. for crossspecies amplification tests. Polymorphism of microsatellite markers was evaluated in one population each of R. evenia, $R$. gayana, and $R$. gracilis, the most common species on Robinson Crusoe Island.

Total genomic DNA was extracted from leaf tissue by the cetyltrimethylammonium bromide method (Doyle and Doyle 1987) or Qiagen DNeasy 96 Plant Kit (Qiagen, Hilden, Germany). The extracted DNA of $R$. masafuerae was sequenced with one-fourth of the run on $1 / 8$ of a $70 \times 75$ PicoTiterPlate using a multiplex identifier in 454 Genome Sequencer FLX System (Roche Applied Science, Penzberg, Germany) of LGC Genomics (Berlin, Germany). A total of 32,468 reads with an average length of $425 \mathrm{bp}$ was generated.

The design for primer pairs was conducted with QDD 2.1 (Meglécz et al. 2010) using default settings. A total of 201 unique microsatellite regions contained pure/compound dinucleotide (140 regions) and trinucleotide microsatellite sequences (61 regions) with more than five repetitions, and primer designable flanking regions were found. First, a cross-species amplification test was performed in 24 selected primer pairs (Table 1) using the Qiagen Multiplex PCR plus Kit (Qiagen, Hilden, Germany) with the 5'-tailed primer method (Boutin-Ganache et al. 2001) with CAG-tailing (5'-CAGTCGGGCGTCATCA-3') and the PIG tailing (5'-GTTT- $\left.3^{\prime}\right)$ method (Brownstein et al. 1996) following Takayama et al. (2011). We applied single-plex PCR in touchdown thermal cycling programs as follows: initial denaturation at $95{ }^{\circ} \mathrm{C}$ for $5 \mathrm{~min}$, followed by first 15 cycles of denaturation at $95^{\circ} \mathrm{C}$ for $30 \mathrm{~s}$, annealing at $63{ }^{\circ} \mathrm{C}$ for $90 \mathrm{~s}$ (decreased $0.5^{\circ} \mathrm{C}$ per cycle), and extension at $72{ }^{\circ} \mathrm{C}$ for $60 \mathrm{~s}$; and by second 25 cycles of denaturation at $95{ }^{\circ} \mathrm{C}$ for $30 \mathrm{~s}$, annealing at $55^{\circ} \mathrm{C}$ for $90 \mathrm{~s}$, and extension at $72{ }^{\circ} \mathrm{C}$ for $60 \mathrm{~s}$; a final extension step was performed at $60{ }^{\circ} \mathrm{C}$ for $30 \mathrm{~min}$. An automated sequencer (ABI 3130xl, Applied Biosystems, CA, USA) and GeneMarker (SoftGenetics LLC, PA, USA) were used for scoring of the PCR products.

Next, we selected the ten best of the 24 markers, and confirmed the polymorphism using multiple individuals of three populations, one from each of the three species (Table 2). We applied multi-plex PCR as follows: RM-HD5GH, RM-G3THW, RM-HCT78 with 6-FAM, RM-HIFPY, RM-HBJ9H, RM-HJIWZ with VIC, RMHMDCO, RM-HBZZR with NED, RM-HGNFW, RMHGC8M with PET. Two to 17 alleles per locus were detected in the three populations, and expected heterozygosity ranged from 0.000 to 0.847 (Table 2). A significant heterozygote deficiency was detected for zero to two markers in each population, and no significant linkage disequilibrium between markers was observed in both populations $(P<0.05$, after Bonferroni correction) using GENEPOP 4.0 (Raymond and Rousset 1995). Ten microsatellite markers present easily scorable polymorphic peaks in the six species of Robinsonia, rendering these markers useful for populational genetic studies.

Acknowledgments We are grateful to the Corporación Nacional Forestal of Chile (CONAF), the Armada de Chile, and the Departamento de Botánica, Universidad de Concepción, Chile, for supporting field research. This work was supported by a Japan Society for the Promotion of Science (JSPS) Postdoctoral Fellowship for Research Abroad, grant number 526 to KT, and the Austrian National Science Foundation (FWF), grant number P21723-B16 to TS.

Open Access This article is distributed under the terms of the Creative Commons Attribution License which permits any use, distribution, and reproduction in any medium, provided the original author(s) and the source are credited. 


\section{References}

Boutin-Ganache I, Raposo M, Raymond M, Deschepper CF (2001) M13-tailed primers improve the readability and usability of microsatellite analyses performed with two different allelesizing methods. Biotechniques 31:24-28

Brownstein MJ, Carpten JD, Smith JR (1996) Modulation of nontemplated nucleotide addition by Taq DNA polymerase: primer modifications that facilitate genotyping. Biotechniques 20: $1004-1010$

Caujape-Castells J, Tye A, Crawford DJ, Santos-Guerra A, Sakai A, Beaver K, Lobin W, Florens FBV, Moura M, Jardim R, Gomes I, Kueffer C (2010) Conservation of oceanic island floras: present and future global challenges. Perspect Plant Ecol Evol Syst 12:107-129

Crawford DJ, Stuessy TF, Haines DW, Cosner MB, Silva M, Lopez P (1992) Allozyme diversity within and divergence among four species of Robinsonia (Asteraceae, Senecioneae), a genus endemic to the Juan Fernandez Islands, Chile. Am J Bot 79:962-966

Danton P, Perrier C (2006) Nouveau catalogue de la flore vasculaire del'archipel Juan Fernández. Acta Bot Gall 153:399-587

Doyle J, Doyle J (1987) A rapid DNA isolation procedure for small quantities of fresh leaf tissue. Phytochem Bull 9:11-15

Frankham R (1997) Do island populations have less genetic variation than mainland populations? Heredity 78:311-327

Kier G, Kreft H, Lee TM, Jetz W, Ibisch PL, Nowicki C, Mutke J, Barthlott W (2009) A global assessment of endemism and species richness across island and mainland regions. Proc Nat Acad Sci USA 106:9322-9327

Marticorena C, Stuessy TF, Baeza M (1998) Catálogo de la flora vascular del Archipiélago de Juan Fernández, Chile. Gayana Bot $55: 187-211$

Meglécz E, Costedoat C, Dubut V, Gilles A, Malausa T, Pech N, Martin JF (2010) QDD: a user-friendly program to select microsatellite markers and design primers from large sequencing projects. Bioinformatics 26:403-404

Pelser PB, Nordenstam B, Kadereit JW, Watson LE (2007) An ITS phylogeny of tribe Senecioneae (Asteraceae) and a new delimitation of Senecio L. Taxon 56:1077-1104

Pelser PB, Tepe EJ, Kennedy AH, Watson LE (2010) The fate of Robinsonia (Asteraceae): sunk in Senecio, but still monophyletic? Phytotaxa 5:31-46

Raymond M, Rousset F (1995) GENEPOP (version 1.2): population genetics software for exact tests and ecumenism. J Hered $86: 248-249$

Ricci M (2006) Conservation status and ex situ cultivation efforts of endemic flora of the Juan Fernández Archipelago. Biodivers Conserv 15:3111-3130

Sanders RW, Stuessy TF, Marticorena C, Silva OM (1987) Phytogeography and evolution of Dendroseris and Robinsonia, treeCompositae of the Juan Fernandez Islands. Opera Botanica 92:195-215

Sang T, Crawford DJ, Stuessy TF, Silva OM (1995) ITS sequences and the phylogeny of the genus Robinsonia (Asteraceae). Syst Bot 20:55-64

Stuessy TF, Crawford DJ, Marticorena C (1990) Patterns of phylogeny in the endemic vascular flora of the Juan Fernandez Islands, Chile. Syst Bot 15:338-346

Stuessy TF, Foland KA, Sutter JF, Sanders RW, Silva M (1984) Botanical and geological significance of potassium-argon dates from the Juan Fernandez Islands. Science 225:49-51

Takayama K, López P, König C, Kohl G, Novak J, Stuessy TF (2011) A simple and cost-effective approach for microsatellite isolation in non-model plant species using small-scale 454 pyrosequencing. Taxon 60:1442-1449 